\title{
The Effects of Natural Weathering on Color Stability of Impregnated and Varnished Wood Materials
}

\author{
Turkay Turkoglu, ${ }^{1}$ Ergun Baysal, ${ }^{2}$ and Hilmi Toker $^{2}$ \\ ${ }^{1}$ Department of Forestry, Koycegiz Vocational School, Mugla Sitki Kocman University, 48800 Mugla, Turkey \\ ${ }^{2}$ Faculty of Technology, Wood Science and Technology, Mugla Sitki Kocman University, 48000 Mugla, Turkey \\ Correspondence should be addressed to Turkay Turkoglu; turkayturkoglu@mu.edu.tr
}

Received 10 February 2015; Revised 15 April 2015; Accepted 20 April 2015

Academic Editor: Peter Majewski

Copyright (c) 2015 Turkay Turkoglu et al. This is an open access article distributed under the Creative Commons Attribution License, which permits unrestricted use, distribution, and reproduction in any medium, provided the original work is properly cited.

\begin{abstract}
The aim of this study was to investigate effects of natural weathering on color stability of Scots pine (Pinus sylvestris L.) and Oriental beech (Fagus orientalis L.) impregnated with some chemicals [tanalith-E (TN-E), adolit-KD5 (AD-KD5), and chromated copper arsenate (CCA)] and then varnished [synthetic varnish (SV) and polyurethane varnish (PV)]. While applying varnish increased lightness, impregnation decreased lightness of the wood specimens before natural weathering. Natural weathering caused greenish, bluish, and dark color tones of the wood surface. Total color change was increased with increasing exposure times in natural weathering. Untreated (control) wood specimens exhibited higher color changes than the other wood specimens in all the stages of natural weathering. The total color changes of untreated Oriental beech specimens were less than untreated Scots pine specimens. The color stability of impregnated and varnished wood specimens gave better results than untreated and solely varnished wood specimens after natural weathering. The best color stability was obtained from both Oriental beech and Scots pine wood impregnated with TN-E before PV coating.
\end{abstract}

\section{Introduction}

Wood is one of the most important natural materials used for aesthetic, engineering, and structural applications $[1,2]$. Wood materials are usually exposed to solar radiation, water, wind, and dust during their useful life, when used outdoor [3]. Unfortunately, wood is susceptible to environmental factors just like other biological materials $[4,5]$. A variety of different environmental factors degrade its main chemical components, lignin, cellulose, and hemicelluloses $[2,6,7]$. The depolymerization of lignin and cellulose leads to a reduction in some physical, chemical, and biological properties of wood [8]. The main factor that causes the greatest changes in the wood surface properties during outdoor exposure is sunlight [9-11]. The photon energy in sunlight (ultraviolet, visible, and infrared light) is extremely harmful, initiating a wide variety of chemical changes in the wood surfaces [12]. Weathering is the general term used to define the degradation of materials exposed to the weather [13], initially causing changes in the wood surface's color [14]. Color is a basic visual feature for wood and wood based products [15]. Nevertheless, wood can be chemically modified to minimize specific problems such as moisture absorption, microbial attack, swelling, and shrinkage, as well as susceptibility to photodegradation [16-18]. Surface treatment of wood with inorganic chemicals and impregnation has been suggested among the effective methods to decrease the negative effect of weathering on wood $[12,17,19]$. The application of clear coating is the easiest and most common method for protecting wood against natural weathering $[5,20]$. However, the coating thickness decreases with increasing weathering time and a tissue deformation below the coating surface occurs during weathering [21]. Impregnation with wood preservatives followed by the application of durable coatings or a varnish/paint makes wood more durable to photochemical degradation, dimensional changes, and biological organisms and increases the service life of treated wood [12, 19, 22, 23]. Chromated copper arsenate (CCA) has provided long-term protection against weathering and erosion [24, 25], but it is no longer being produced for use in most residential settings, 
because it contains chromium and arsenic. Nowadays, several new copper-based wood preservatives such as tanalith-E (TN-E) and adolit-KD5 (AD-KD5) are being used in the forest products industry instead of CCA. It is generally known that new copper-based wood preservatives and varnishes retard or prevent photodegradation [23]. The effect of accelerated weathering on color characteristics of Scots pine and alder wood impregnated with alkylammonium compounds (AACS), CCA, ammoniacal copper quat (ACQ 1900 and ACQ 2200), TN-E 3491, and wolmanit CX-8 was investigated by Temiz et al. [8]. Yalinkilic et al. investigated the outdoor performance of Scots pine and chestnut wood treated with chromium-copper-boron (CCB) and applied with polyurethane varnish (PV) or alkyd-based synthetic varnish (SV). They reported that CCB impregnation greatly stabilized the surface color and reduced mass loss of wood. It was also claimed that preservative treatment followed by a surface coating system protected wood in long-term outdoor conditions [19]. Another research about outdoor weathering durability of obeche, red beech, spruce, and fir wood treated with CCB was carried out by Sell and Feist. They found that CCB-coated wood has high resistance and protective effect against weathering [26]. The comparison of new copperbased wood preservatives with CCA and their performance testing is important in determining consumer expectation of these new products.

This study investigates the effect of natural weathering on color stability of Scots pine and Oriental beech wood impregnated with copper-based wood preservatives including TNE, AD-KD5, and CCA and applied with PV or SV. The effect of 3- and 6-month natural weathering on color stability was evaluated.

\section{Materials and Methods}

\subsection{Materials}

2.1.1. Preparation of Test Specimens and Chemicals. Wood specimens were prepared from air-dried sapwood of Scots pine and Oriental beech for impregnation treatment with dimensions of 10 (radial) $\times 100$ (tangential) $\times 150$ (longitudinal) $\mathrm{mm}$. They were oven dried at $50 \pm 5^{\circ} \mathrm{C}$ until constant weight. Wood specimens were impregnated with three preservatives containing CCA, AD-KD5, and TN-E. Aqueous solutions of impregnation chemicals were dissolved in distilled water to a concentration of 4 percent. $\mathrm{pH}$ degrees of impregnation solutions are 7.76 for CCA, 8.39 for AD-KD5, and 8.25 for TN-E. An alkyd-based SV and a solvent-based two-component PV were applied after the impregnation process in this study.

\subsection{Methods}

2.2.1. Impregnation Process. The wood specimens were impregnated with 4 percent aqueous solution of CCA, ADKD5, and TN-E according to the ASTM D1413-07e1 [27]. All specimens were conditioned at $20^{\circ} \mathrm{C}$ and $65 \%$ relative humidity for two weeks before tests. Calculating the amount of preservative impregnation chemicals absorbed by the wood specimens, as kilograms per cubic meter $\left(\mathrm{kg} / \mathrm{m}^{3}\right)$ of wood, was done using the following formula:

$$
\text { Retention }\left(\frac{\mathrm{Kg}}{\mathrm{m}^{3}}\right)=\frac{G \times C}{V} \times 10 \text {, }
$$

where $G=\left(T_{2}-T_{1}\right)$ is grams of treatment solution absorbed by the wood specimens ( $T_{1}$ is the weight of the wood specimens before impregnation, and $T_{2}$ is the weight of the wood specimens after impregnation), $C$ is grams of preservative in $100 \mathrm{~g}$ of the treatment solution, and $V$ is volume of the wood specimen as $\mathrm{cm}^{3}$.

2.2.2. Coating. SV and PV were supplied by merchants and used according to the producer's instructions. The viscosity of the varnishes was determined according to the manufacturer's directions and was found to be $18 \mathrm{~s}$ (DIN 4 cup) at $20 \pm 2^{\circ} \mathrm{C}$ for both varnishes. Hardener and thinner mixture ratios were determined according to the manufacturer's suggestions. The varnish was applied to all surfaces and sides of the wood specimens with a spray gun according to the ASTM D3023-98 standard [28]. Filler was not used on the wood surfaces in order to avoid potential interference with the surface characteristics of the wood. Instead of using filler, varnish was applied twice for PV and 4 times for SV. The first coating applied to the wood surface was for filling the voids, and the second and upper coatings were applied for top coating. Sufficient time for layer settling was allowed between successive applications until the target retention of $100 \mathrm{~g} / \mathrm{m}^{2}$ for the primer and $100 \mathrm{~g} / \mathrm{m}^{2}$ for the top coating was reached, controlled by consecutive weighing. Specimens were left in ambient conditions for $24 \mathrm{~h}$ according to the manufacturer's recommendations after the first coating, and then surfaces were gently sanded using a fine-grit sandpaper (220 grit) to obtain a smooth surface before the top coating. After the top coating of varnish was applied to the surfaces, specimens were conditioned for 3 weeks [12].

2.2.3. Natural Weathering. Wood specimens were prepared for weathering exposure according to ASTM D7787 [29]. They were exposed to weathering conditions during spring and summer (from March to August) in 2011. The site is situated at Mugla Sitki Kocman University $\left(37^{\circ} 09^{\prime} \mathrm{N}\right.$ and $28^{\circ} 22^{\prime} \mathrm{E}, 670 \mathrm{~m}$ above sea level) in Mugla, Southern Aegean Region of Turkey. Weather conditions of Mugla during weathering were given in Table 1 [30].

The exposure rack was positioned so that the exposed specimens were at an angle of $45^{\circ}$ facing south. Wood specimens were set outside for weathering exposure according to ASTM G7/G7M-13 [31]. Exposure covered a period of 6 months. The wood specimens were removed at 3-month intervals for performance evaluation. The color parameters were measured on the exposed surfaces of the wood specimens.

2.2.4. Color Test. The CIE $L^{*} a^{*} b^{*}$ color system was used to compare exposure directions of natural weathering (Figure 1). 
TABle 1: Weather conditions of Mugla from March to August in 2011.

\begin{tabular}{|c|c|c|c|c|c|c|}
\hline Months & Mar & Apr & May & Jun & Jul & Aug \\
\hline Average temperature $\left({ }^{\circ} \mathrm{C}\right)$ & 8.6 & 11.7 & 16.4 & 22.8 & 27.9 & 27.5 \\
\hline The highest temperature $\left({ }^{\circ} \mathrm{C}\right)$ & 19.9 & 21.7 & 29.1 & 35.9 & 38.4 & 38.1 \\
\hline The lowest temperature $\left({ }^{\circ} \mathrm{C}\right)$ & -4.9 & 1.4 & 6.8 & 13 & 12.1 & 13.5 \\
\hline Sunbathing time (hour) & 5.4 & 5.5 & 6.8 & 10 & 11.2 & 10.4 \\
\hline The number of the rainy days & 11 & 17 & 9 & 6 & 0 & 0 \\
\hline Rainfall per month $\left(\mathrm{kg} / \mathrm{m}^{2}\right)$ & 29.8 & 80.4 & 59.4 & 17.4 & 0 & 0 \\
\hline Humidity (\%) & 74.6 & 75.2 & 67.8 & 53.6 & 38.8 & 39.2 \\
\hline
\end{tabular}

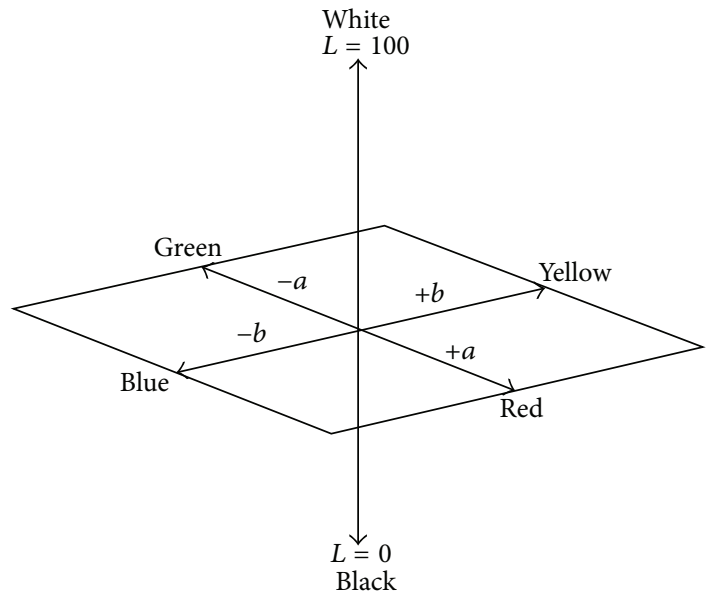

Figure 1: The CIE $L^{*} a^{*} b^{*}$ color space.

The $L^{*}$ axis represents the lightness, while $a^{*}$ and $b^{*}$ are the chromaticity coordinates. The $+a^{*}$ and $-a^{*}$ parameters represent red and green, respectively. The $+b^{*}$ parameter represents yellow, whereas $-b^{*}$ represents blue. $L^{*}$ can vary from 100 (white) to zero (black) [32]. The colors of the specimens were measured by a colorimeter (X-Rite SP Series Spectrophotometer) before and after natural weathering. The measuring spot was adjusted to be equal to or not more than one-third of the distance from the centre of this area to the receptor field stops. The color difference $\left(\Delta E^{*}\right)$ was determined for each wood according to ASTM D2244-14 [33]:

$$
\begin{aligned}
\Delta a^{*} & =a_{f}^{*}-a_{i}^{*}, \\
\Delta b^{*} & =b_{f}^{*}-b_{i}^{*}, \\
\Delta L^{*} & =L_{f}^{*}-L_{i}^{*}, \\
\left(\Delta E^{*}\right) & =\left(\left(\Delta a^{*}\right)^{2}+\left(\Delta b^{*}\right)^{2}+\left(\Delta L^{*}\right)^{2}\right)^{1 / 2},
\end{aligned}
$$

where $\Delta a^{*}, \Delta b^{*}$, and $\Delta L^{*}$ are the changes between the initial and final interval values. Ten replications were made for each group.

\section{Results and Discussion}

\begin{tabular}{|c|c|c|c|}
\hline \multirow{2}{*}{$\begin{array}{l}\text { Impregnation } \\
\text { solution }\end{array}$} & \multirow{2}{*}{ Concentration (\%) } & \multicolumn{2}{|c|}{ Retention $\left(\mathrm{Kg} / \mathrm{m}^{3}\right)$} \\
\hline & & Scots pine & $\begin{array}{c}\text { Oriental } \\
\text { beech }\end{array}$ \\
\hline CCA & 4 & 32.7 & 27.6 \\
\hline AD-KD5 & 4 & 30.7 & 23.1 \\
\hline TN-E & 4 & 35.5 & 28.8 \\
\hline
\end{tabular}

In this study, synthetic or polyurethane varnish was applied to Scots pine and Oriental beech wood specimens after
TABLE 2: Retentions of wood specimens.

being impregnated with three different chemicals except for the control specimens. The wood specimens were exposed to natural weathering for two periods, 3 months and 6 months. The effects of natural weathering on color stability of impregnated and varnished wood materials are evaluated in this section. Retentions of different impregnation solutions on Scots pine and Oriental beech wood are given in Table 2.

Retentions were calculated as 30.7 to $35.5 \mathrm{~kg} / \mathrm{m}^{3}$ in Scots pine and 23.1 to $28.8 \mathrm{~kg} / \mathrm{m}^{3}$ in Oriental beech. The highest retention amounts determined in Scots pine and Oriental beech treated with TN-E were $35.5 \mathrm{~kg} / \mathrm{m}^{3}$ and $28.8 \mathrm{~kg} / \mathrm{m}^{3}$, respectively. The lowest retention amounts determined in Scots pine and Oriental beech treated with $\mathrm{AD}-\mathrm{KD} 5$ were $30.7 \mathrm{~kg} / \mathrm{m}^{3}$ and $23.1 \mathrm{~kg} / \mathrm{m}^{3}$, respectively.

3.1. Effect of Natural Weathering on Color Stability. Table 3 presents $L^{*}, a^{*}$, and $b^{*}$ values of untreated (control), solely varnished, and impregnated and varnished Oriental beech specimens before natural weathering and also illustrates the values of change for all three color parameters $\left(\Delta L^{*}, \Delta a^{*}\right.$, and $\left.\Delta b^{*}\right)$, as well as the total color changes $\left(\Delta E^{*}\right)$ of the wood specimens after 3 months and 6 months of natural weathering.

Before natural weathering, while $L^{*}$ value of untreated (control) Oriental beech wood specimens was $62.30, L^{*}$ values of solely PV and solely SV coated wood specimens were 68.07 and 63.54, respectively. Applying varnish made the wood color lighter and increased the yellowness of the color on the wood surface. The decrease in $L^{*}$ value of wood specimens indicates that the specimens become darker [12]. Impregnated and varnished wood specimens become slightly darker than control wood specimens. However, wood specimens impregnated with TN-E before varnish coating were darker compared to the others. The darkening of impregnated and varnished wood specimens might be due to the impregnation materials. While $a^{*}$ values changed from 


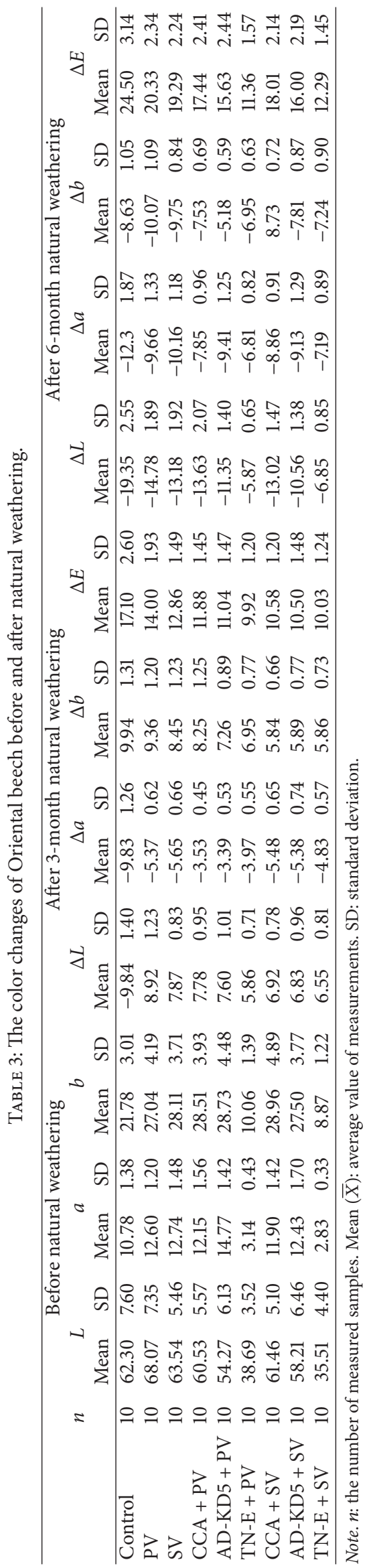


2.83 to $14.77, b^{*}$ values changed from 8.87 to 28.96 before natural weathering. Oriental beech wood specimens had light, yellowish, and reddish color before natural weathering. The pale yellow color of the control specimens is primarily reflective of the color of the lignin component of wood [34].

After 3-month natural weathering, $\Delta a^{*}$ values were found to be -3.39 to -9.83 . The negative $\Delta a^{*}$ values showed that the wood surface turned from red to green. $\Delta b^{*}$ values changed from 5.84 to 9.94. Positive $\Delta b^{*}$ values indicate that wood specimens maintained a yellowish tone. $\Delta L^{*}$ is the most sensitive parameter of the wood surface quality [35], but there was a dramatic decline in $\Delta L^{*}$ values after 3-month natural weathering. Therefore, the wood surface became darker than the values before natural weathering.

After 6-month natural weathering, the $\Delta L^{*}$ value of control wood specimens decreased substantially. Depolymerization of the lignin can also bring about the darkening of the wood surface $[8,12,36]$. According to the $\Delta b^{*}$ values, the wood surface changed from yellow to blue after 6-month natural weathering. The decrease of yellowness with weathering time may be attributed to the reduction of paraquinones (chromophoric structures) to hydroquinones, which results in photobleaching [37]. The least change in $\Delta b^{*}$ value was AD-KD5 with PV coated for Oriental beech wood specimens after 6-month natural weathering. TN-E impregnation before varnishing resulted in the least $\Delta a^{*}$ changes. The greatest $\Delta a^{*}$ changes for Oriental beech wood specimens occurred in the control specimens at the end of 6 months.

The color changes of Scots pine before and after natural weathering are shown in Table $4 . L^{*}$ value of untreated (control) Scots pine wood specimens was 70.52. Lightness $\left(L^{*}\right)$ of wood specimens impregnated and varnished is slightly lower than solely varnished wood specimens before natural weathering. In other words, while the lightness of solely varnished wood specimens increased, impregnated and varnished wood specimens became darkener. $L^{*}$ values of wood specimens impregnated and varnished and solely varnished were observed from 45.02 to $78.85 . a^{*}$ and $b^{*}$ values were found positive before natural weathering. However, the impregnation materials decreased the red color tone value in wood materials [38]. It is reported that the impregnation of some softwoods with some chemicals has increased the yellow color tone [39]. Baysal et al. also reported that three color parameters $\left(L^{*}, a^{*}\right.$, and $\left.b^{*}\right)$ of Scots pine decreased after the AD-KD5 impregnation process [40]. Our results are in agreement with these researchers' findings. After 3-month natural weathering, $\Delta a^{*}$ and $\Delta b^{*}$ values were found to have positive values. In other words, yellow and red tone of wood specimens had not changed markedly. However, $\Delta L^{*}$ values of untreated (control) Scots pine wood specimens decreased reasonably after 3-month natural weathering. Although $\Delta L^{*}$ is the most sensitive parameter, $\Delta L^{*}$ values of untreated (control) Scots pine wood specimens decreased considerably after 6-month natural weathering. The lightness values of all the specimens decreased after natural weathering but lightness of the control specimens was more than the others. While the tone of Scots pine wood specimens changed from red to green on the red-green scale, they changed from yellow to blue on yellow-blue scale after 6-month natural

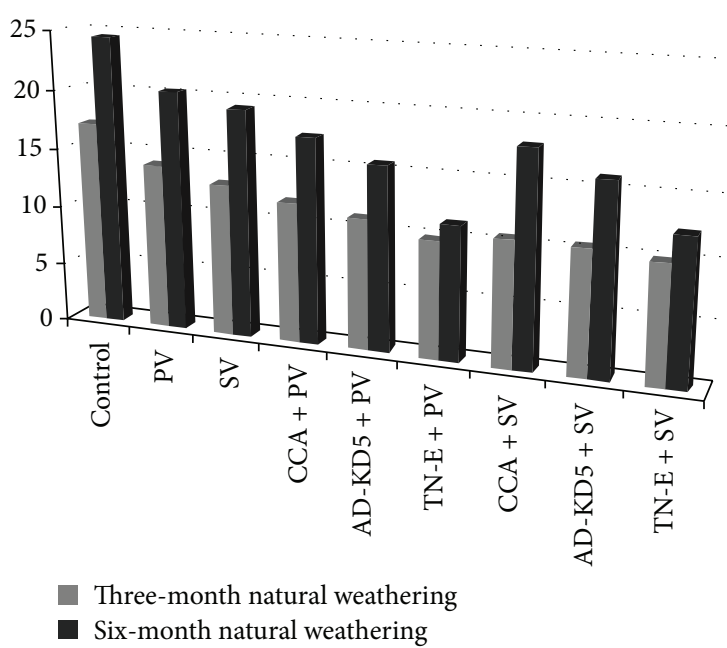

FIGURE 2: Total color changes $(\Delta E)$ of Oriental beech after 3- and 6-month natural weathering. Note: it is drawn by using the average value of $\Delta E$. See Table 3 for standard deviations.

weathering. Rüther and Jelle investigated color changes of wooden boards outdoors both on a test house and in the laboratory. They measured in rack before natural weathering that $L^{*}, a^{*}$, and $b^{*}$ values of Scots pine heartwood wood specimens were $75.6,10.2$, and 10.2, respectively, and after natural weathering, three color parameters $\left(L^{*}, a^{*}\right.$, and $\left.b^{*}\right)$ were found to be $49.6,-2.5$, and 5.3 , respectively [41]. The least $\Delta a^{*}$ changes occurred with TN-E impregnation before $\mathrm{PV}$ varnishing and $\mathrm{AD}-\mathrm{KD} 5$ with $\mathrm{SV}$ coating resulted in the greatest $\Delta a^{*}$ changes for Scots pine wood specimens after 6month natural weathering. The Scots pine wood specimens impregnated with TN-E had minimal $\Delta L^{*}$ changes for both SV and PV coated after 6-month natural weathering. Total color changes $\left(\Delta E^{*}\right)$ of Oriental beech after 3-and 6-month natural weathering are shown in Figure 2.

While the $\Delta E^{*}$ values of Oriental beech wood specimens changed from 9.92 to 17.10 after 3-month natural weathering, at end of 6 months $\Delta E^{*}$ values changed from 11.36 to 24.50 for Oriental beech wood specimens. The highest $\Delta E^{*}$ was observed on the untreated (control) Oriental beech specimens. Untreated Oriental beech wood specimens exhibited higher color changes than coated specimens in 3- and 6month natural weathering. However, Fufa et al. reported that color changes of the varnished specimens become the highest in untreated (control) specimens at long periods of natural weathering [42]. Our results show that the trend of discoloration of impregnated and varnished specimens was lower than the varnished and control specimens. Total color changes $(\Delta E)$ of Scots pine after 3- and 6-month natural weathering are shown in Figure 3.

The highest $\Delta E^{*}$ was observed on the untreated (control) Scots pine after 3-and 6-month natural weathering. While the $\Delta E^{*}$ values of Scots pine wood specimens changed from 10.10 to 22.02 after 3-month natural weathering, $\Delta E^{*}$ values of Scots pine wood specimens changed from 12.03 to 33.15 after 6-month natural weathering. Fufa et al. reported that untreated specimens exhibited higher color changes than 


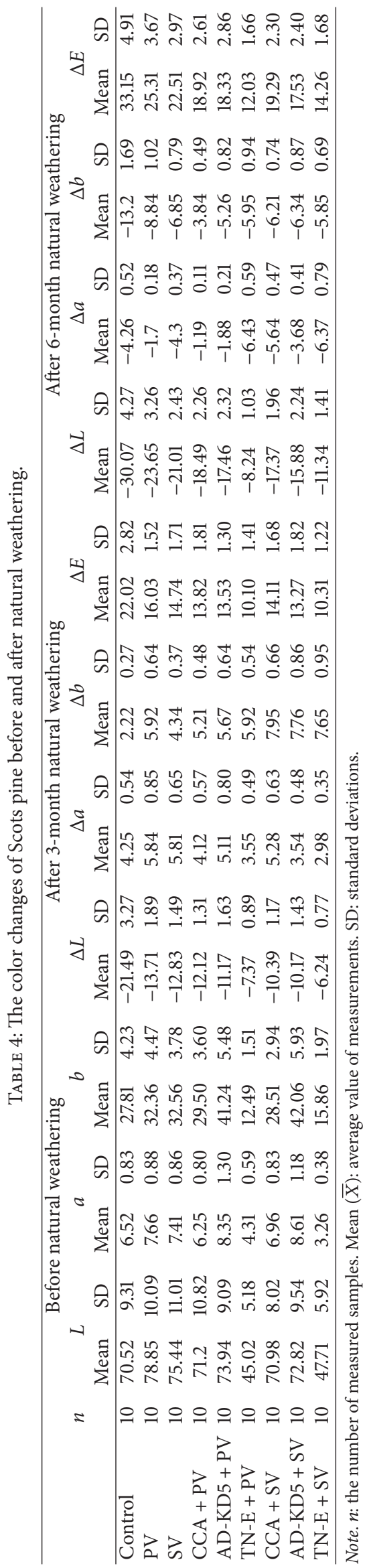




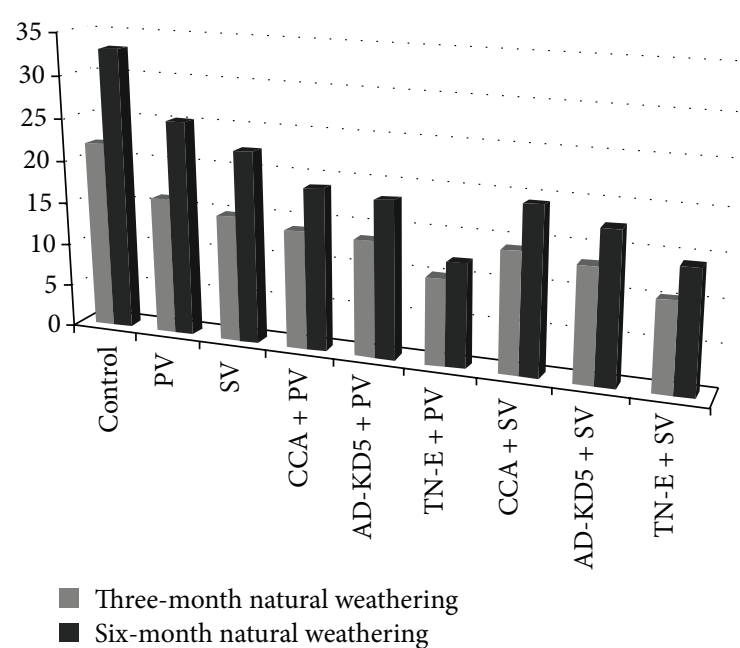

Figure 3: Total color changes $(\Delta E)$ of Scots pine after 3- and 6month natural weathering. Note: it is drawn by using the average value of $\Delta E$. See Table 4 for standard deviations.

varnished or coated specimens in the short period of natural weathering [42]. However, for longer performance of coatings at exterior applications improvements of the coatings are crucial. It is known that the maintenance of wood coatings in exterior use is crucial to the performance and durability during weathering [43].

As the result, the best color stability was TN-E with PV coating for both Oriental beech and Scots pine wood specimens. TN-E treatments both slowed down photodegradation by retarding the formation of carbonyl groups. The light resistance of TN-E-treated wood likely results from $\mathrm{Cu}$ (II) chelating with functional groups in wood. These chelates can photostabilize wood and retard the formation of carbonyl groups $[8,44]$. Otherwise solely PV coating did not contribute to stabilizing the wood color. UV light has a crucial role in the weathering degradation of polyurethane coatings [45]. Solely PV coating generally produced slightly better color stability than solely SV coating after natural weathering. However, Baysal et al. found that, in specimens where color changes of impregnated and varnished Scots pine after accelerated weathering occurred, solely SV coated wood specimens were observed to have better color stability than PV [12]. This situation can be explained because wood specimens in our study were exposed to natural weather conditions such as sunlight and rain. Moreover, Budakçi et al. found that the color stability of wood specimens after ageing tests could be ordered in the following way: acrylic varnish > polyurethane varnish $>$ cellulosic varnish [46]. The impregnated wood with copper-based formulations before PV coating was more effective in stabilizing wood color than PV or SV coating alone [12]. Wood specimens impregnated with TN-E before PV coating showed better color stability than the others in this study. Double treatment of wood with chemicals and varnishes is necessary to extend the service life of a wood. Baysal and Grüll et al. recommended that the application of a maintenance coat is important $[22,43]$. The color change is attributed to the carbonyl groups of the conjugated ketones, aldehydes, and quinines resulting from lignin and other compound modifications [47], and it depends on the formation of carbonyl groups generated during photodegradation of the wood [9]. TN-E which includes copper might reduce photodegradation by retarding the formation of carbonyl groups and delignification. Similar findings were also obtained on copper-based formulations $[8,47]$. Copper forms certain complexes with wood components, such as copper-cellulose complexes, copper-lignin complexes, and crystalline or amorphous inorganic/organic copper compounds, and reduces the degradation of the wood surface from weathering factors $[8,47]$. Wood ion complexes formed at the wood surfaces can provide the wood surface with resistance by blocking the free phenolic groups [47]. Similar ion complexes can be formed with copper-based formulations and wood components, and these complexes might reduce radials, which stabilize the color of the wood [48].

\section{Conclusions}

Wood materials used in exterior applications are exposed to several climate factors including solar radiation, water, temperature changes, wind, and erosion [49]. These factors affect the color stability of wood in particular. This study investigated the effect of natural weathering on color stability of impregnated and varnished Scots pine and Oriental beech wood. While TN-E, AD-KD5, and CCA were used as impregnation chemicals, polyurethane and synthetic varnishes were used as varnish in this study. It was observed that the retention of Scots pine is higher than the retention of Oriental beech.

Initially, Scots pine and Oriental beech control wood specimens had lighter, natural reddish, and yellowish color tones. Varnishing them increased lightness, yellowness, and redness of the color of the wood surface, but impregnating them decreased lightness of the wood specimens compared to control specimens. The lightness values of all the specimens decreased within natural weathering. However, untreated (control) wood specimens exhibited higher color changes than the other specimens in all stages of natural weathering. $\Delta a^{*}$ and $\Delta b^{*}$ decreased with increasing exposure times in natural weathering for both Scots pine and Oriental beech wood specimens.

It can be concluded that untreated (control), solely varnished, and both impregnated and varnished wood specimens shifted from red to green on the red-green scale and from yellow to blue on yellow-blue scale with increasing exposure times in natural weathering. The highest total color change was observed on the untreated (control) Scots pine after 3- and 6-month natural weathering. The total color changes of untreated Oriental beech specimen were less than that of untreated Scots pine specimens. Finally, the best color stability was obtained by impregnation with TN-E before PV coating for both Oriental beech and Scots pine wood specimens after the natural weathering. The impregnated wood with copper-based formulations before PV coating was more effective in stabilizing wood color. The photostabilization of wood by copper-based impregnation may be explained by the 
retarding of the formation of carbonyl groups and reduced delignification during weathering.

\section{Conflict of Interests}

The authors declare no conflict of interests.

\section{References}

[1] I.-U. Bhat, H. P. S. Abdul Khalil, K. B. Awang, I. O. Bakare, and A. M. Issam, "Effect of weathering on physical, mechanical and morphological properties of chemically modified wood materials," Materials \& Design, vol. 31, no. 9, pp. 4363-4368, 2010.

[2] B. Lesar, M. Pavlič, M. Petrič, A. S. Škapin, and M. Humar, "Wax treatment of wood slows photodegradation," Polymer Degradation and Stability, vol. 96, no. 7, pp. 1271-1278, 2011.

[3] W. C. Feist, R. M. Rowell, and R. J. Barbour, "Outdoor wood weathering and protection," Advances in Chemistry Series, vol. 225, pp. 263-298, 1990.

[4] R. S. Williams and W. C. Feist, "Water repellents and waterrepellent preservatives for wood," General Technical Report FPL-GTR-109, Forest Products Laboratory, Madison, Wis, USA, 1999.

[5] S.-T. Chang and P.-L. Chou, "Photodiscoloration inhibition of wood coated with UV-curable acrylic clear coatings and its elucidation," Polymer Degradation and Stability, vol. 69, no. 3, pp. 355-360, 2000.

[6] K. J. Schmalzl and P. D. Evans, "Wood surface protection with some titanium, zirconium and manganese compounds," Polymer Degradation and Stability, vol. 82, no. 3, pp. 409-419, 2003.

[7] M. Jebrane, G. Sèbe, I. Cullis, and P. D. Evans, "Photostabilisation of wood using aromatic vinyl esters," Polymer Degradation and Stability, vol. 94, no. 2, pp. 151-157, 2009.

[8] A. Temiz, U. C. Yildiz, I. Aydin, M. Eikenes, G. Alfredsen, and G. Çolakoglu, "Surface roughness and color characteristics of wood treated with preservatives after accelerated weathering test," Applied Surface Science, vol. 250, no. 1-4, pp. 35-42, 2005.

[9] K. K. Pandey, "Study of the effect of photo-irradiation on the surface chemistry of wood," Polymer Degradation and Stability, vol. 90, no. 1, pp. 9-20, 2005.

[10] Y. Kataoka, M. Kiguchi, R. S. Williams, and P. D. Evans, "Violet light causes photodegradation of wood beyond the zone affected by ultraviolet radiation," Holzforschung, vol. 61, no. 1, pp. 23-27, 2007.

[11] L. Tolvaj, L. Persze, and L. Albert, "Thermal degradation of wood during photodegradation," Journal of Photochemistry and Photobiology B: Biology, vol. 105, no. 1, pp. 90-93, 2011.

[12] E. Baysal, E. Dizman Tomak, M. Ozbey, and E. Altin, "Surface properties of impregnated and varnished Scots pine wood after accelerated weathering," Coloration Technology, vol. 130, no. 2, pp. 140-146, 2014.

[13] R. S. Williams, Handbook of Wood Chemistry and Wood Composites, Weathering of Wood, Forest Products Laboratory, Madison, Wis, USA, 2005.

[14] O. Ozgenc, S. Hiziroglu, and U. C. Yildiz, "Weathering properties of wood species treated with different coating applications," BioResources, vol. 7, no. 4, pp. 4875-4888, 2012.

[15] I. Aydin and G. Colakoglu, "Effects of surface inactivation, high temperature drying and preservative treatment on surface roughness and colour of alder and beech wood," Applied Surface Science, vol. 252, no. 2, pp. 430-440, 2005.

[16] P. D. Evans, A. F. A. Wallis, and N. L. Owen, "Weathering of chemically modified wood surfaces," Wood Science and Technology, vol. 34, no. 2, pp. 151-165, 2000.

[17] A. Temiz, N. Terziev, M. Eikenes, and J. Hafren, "Effect of accelerated weathering on surface chemistry of modified wood," Applied Surface Science, vol. 253, no. 12, pp. 5355-5362, 2007.

[18] J. Miklečić and V. Jirouš-Rajković, "Accelerated weathering of coated and uncoated beech wood modified with citric acid," Drvna Industrija, vol. 62, no. 4, pp. 277-282, 2011.

[19] M. K. Yalinkilic, R. Ilhan, Y. Imamura et al., "Weathering durability of CCB-impregnated wood for clear varnish coatings," Journal of Wood Science, vol. 45, no. 6, pp. 502-514, 1999.

[20] R. Schwalm, L. Häußling, W. Reich, E. Beck, P. Enenkel, and K. Menzel, "Tuning the mechanical properties of UV coatings towards hard and flexible systems," Progress in Organic Coatings, vol. 32, no. 1-4, pp. 191-196, 1997.

[21] S. Saha, D. Kocaefe, C. Krause, and T. Larouche, "Effect of titania and zinc oxide particles on acrylic polyurethane coating performance," Progress in Organic Coatings, vol. 70, no. 4, pp. 170-177, 2011.

[22] E. Baysal, "Some physical properties of varnish coated wood preimpregnated with copper-chromated boron (CCB) after 3 months of weathering exposure in southern eagen sea region," Wood Research, vol. 53, no. 1, pp. 43-54, 2008.

[23] M. Nejad and P. Cooper, "Exterior wood coatings. Part-1: performance of semitransparent stains on preservative-treated wood," Journal of Coatings Technology Research, vol. 8, no. 4, pp. 449-458, 2011.

[24] W. C. Feist and A. S. Ross, "Performance and durability of finishes on previously coated CCA-treated wood," Forest Products Journal, vol. 45, no. 9, pp. 29-36, 1995.

[25] V. Jirous-Rajkovic, A. Bogner, and D. Radovan, “The efficiency of various treatments in protecting wood surfaces against weathering," Surface Coatings International Part B: Coatings Transactions, vol. 87, no. 1, pp. 15-19, 2004.

[26] J. Sell and W. C. Feist, "Weathering behavior of chromiumcopper-boron treated wood," Holz als Roh- und Werkstoff, vol. 43, pp. 518-523, 1985.

[27] ASTM D1413-07el, "Standard test method for wood preservatives by laboratory soil-block cultures," in Annual Book of ASTM Standards, ASTM, West Conshohocken, Pa, USA, 2007.

[28] ASTM, "ASTM D3023-98. Standard practice for determination of resistance of factory-applied coatings on wood products to stains and reagents," in Annual Book of ASTM Standards, ASTM International, West Conshohocken, Pa, USA, 2013.

[29] ASTM D7787/D7787M-13, "Standard practice for selecting wood substrates for weathering evaluations of architectural coatings," in Annual Book of ASTM Standards, ASTM, West Conshohocken, Pa, USA, 2013.

[30] Turkish State Meteorological Service Database, Meteorological data, 2011, http://www.mgm.gov.tr.

[31] ASTM G7/G7M-13, "Standard practice for atmospheric environmental exposure testing of nonmetallic materials," in Annual Book of ASTM Standards, ASTM, West Conshohocken, Pa, USA, 2013.

[32] X. Zhang, Photo-resistance of alkylammonium compound treated wood [M.S. thesis], University of British Columbia, Vancouver, Canada, 2003. 
[33] ASTM International, "ASTM D2244-14. Standard practice for calculation of color tolerances and color differences from instrumentally measured color coordinates," in Annual Book of ASTM Standards, ASTM International, West Conshohocken, $\mathrm{Pa}$, USA, 2014.

[34] S. Butylina, M. Hyvärinen, and T. Kärki, "A study of surface changes of wood-polypropylene composites as the result of exterior weathering," Polymer Degradation and Stability, vol. 97, no. 3, pp. 337-345, 2012.

[35] E. Baysal, "Surface characteristics of CCA treated scots pine after accelerated weathering," Wood Research, vol. 57, no. 3, pp. 375-382, 2012.

[36] S. C. Ghosh, H. Militz, and C. Mai, "Natural weathering of scots pine (Pinus sylvestris L.) boards modified with functionalised commercial silicone emulsions," BioResources, vol. 4, no. 2, pp. 659-673, 2009.

[37] M. Muasher and M. Sain, "The efficacy of photostabilizers on the color change of wood filled plastic composites," Polymer Degradation and Stability, vol. 91, no. 5, pp. 1156-1165, 2006.

[38] H. Keskin, M. Atar, and A. Ketizmen, "Impacts of impregnation with boric acid and borax on the red colour tone of some hardwoods and varnishes," African Journal of Biotechnology, vol. 8, no. 16, pp. 3958-3963, 2009.

[39] M. Atar, H. Keskin, and M. H. Çolakoğlu, "Effects of impregnation with imersol-AQUA on yellow color tone of some softwoods and varnishes," Journal of Applied Polymer Science, vol. 103, no. 2, pp. 1048-1054, 2007.

[40] E. Baysal, S. Degirmentepe, H. Toker, and T. Turkoglu, "Some mechanical and physical properties of $\mathrm{AD}-\mathrm{KD} 5$ impregnated and thermally modified Scots pine wood," Wood Research, vol. 59, no. 2, pp. 283-296, 2014.

[41] P. Rüther and B. P. Jelle, "Color changes of wood and woodbased materials due to natural and artificial weathering," Wood Material Science \& Engineering, vol. 8, no. 1, pp. 13-25, 2013.

[42] S. M. Fufa, B. P. Jelle, P. J. Hovde, and P. M. Rørvik, "Coated wooden claddings and the influence of nanoparticles on the weathering performance," Progress in Organic Coatings, vol. 75, no. 1-2, pp. 72-78, 2012.

[43] G. Grüll, B. Forsthuber, F. Tscherne, and I. Spitaler, "Weathering indicator for artificial and natural weathering of wood coatings," European Journal of Wood and Wood Products, vol. 72, pp. 681684, 2014.

[44] O. Ozgenc and U. C. Yildiz, "Surface characteristics of wood treated with new generation preservatives after artificial weathering," Wood Research, vol. 59, no. 4, pp. 605-616, 2014.

[45] X. F. Yang, D. E. Tallman, G. P. Bierwagen, S. G. Croll, and S. Rohlik, "Blistering and degradation of polyurethane coatings under different accelerated weathering tests," Polymer Degradation and Stability, vol. 77, no. 1, pp. 103-109, 2002.

[46] M. Budakçi, D. S. Korkut, and R. Esen, "The color changes on varnish layers after accelerated aging through the hot and coldcheck test," African Journal of Biotechnology, vol. 9, no. 24, pp. 3595-3602, 2010.

[47] S. Grelier, A. Castellan, and D. P. Kamdem, "Photoprotection of copper-amine-treated pine," Wood and Fiber Science, vol. 32, no. 2, pp. 196-202, 2000.

[48] S. Schmid, R. D. Webster, and P. D. Evans, "The use of ESR Spectroscopy to assess the photostabilising effects of wood preservatives," in Proceedings of the International Research Group on Wood Preservation Conference, Document IRG/WP 00-20186, Kona, Hawaii, USA, May 2000.
[49] B. George, E. Suttie, A. Merlin, and X. Deglise, "Photodegradation and photostabilisation of wood-the state of the art," Polymer Degradation and Stability, vol. 88, no. 2, pp. 268-274, 2005. 

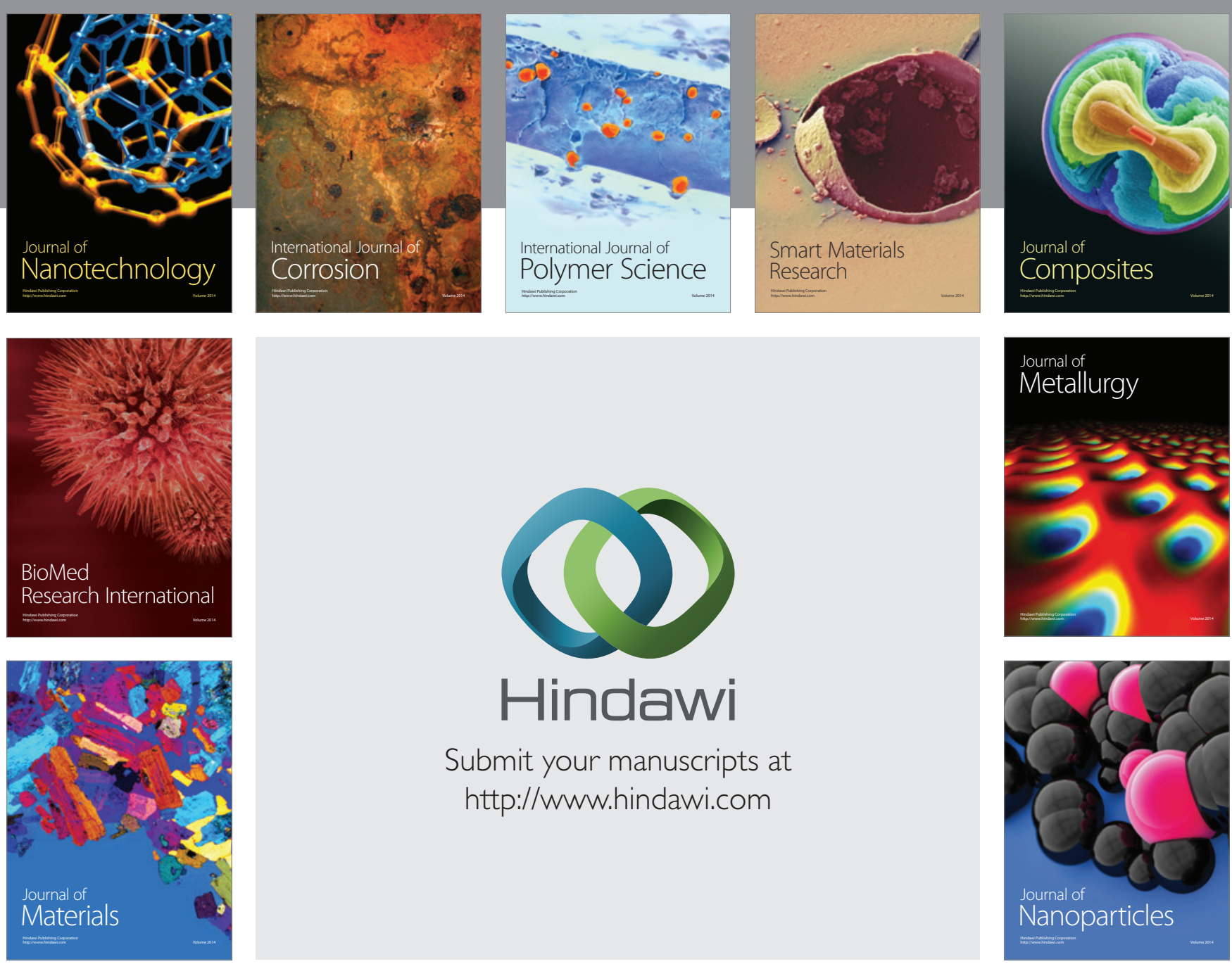

Submit your manuscripts at http://www.hindawi.com
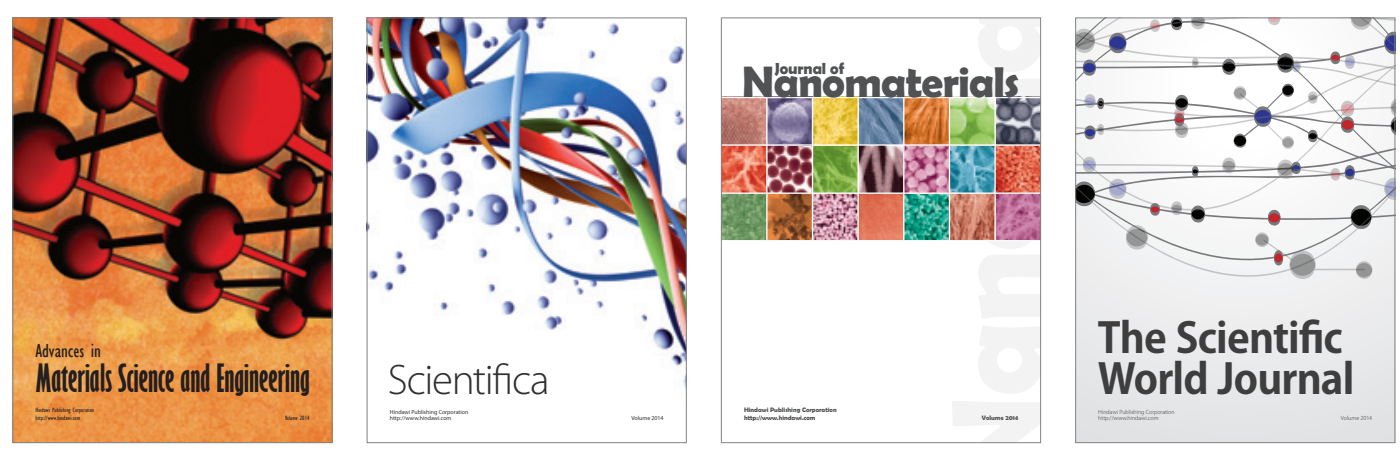

\section{The Scientific World Journal}
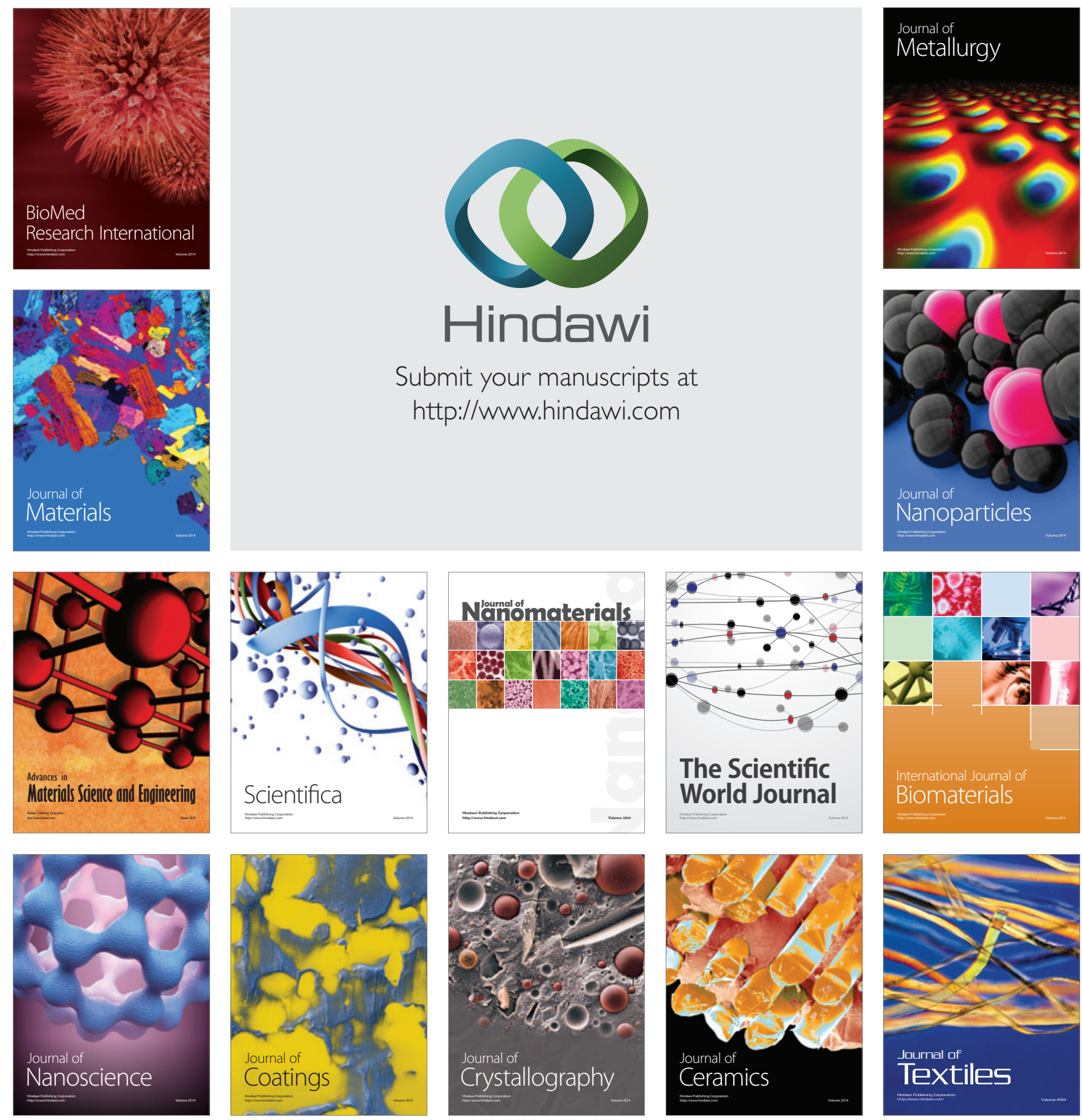